\title{
Characterization of biofilm and corrosion of cast iron pipes in drinking water distribution system with $\mathrm{UV} / \mathrm{Cl}_{2}$ disinfection
}

\author{
Ying Zhu, Haibo Wang, Xiaoxiao Li, Chun Hu*, Min Yang, Jiuhui Qu \\ Key Laboratory of Aquatic Science and Technology, Research Center for Eco-Environmental Sciences, \\ Chinese Academy of Sciences, Beijing 100085, China
}

\section{A R T I C L E I N F O}

Article history:

Received 24 January 2014

Received in revised form

10 April 2014

Accepted 21 April 2014

Available online 2 May 2014

Keywords:

Biofilm

Corrosion

Disinfection

Water quality

Drinking water distribution system

\begin{abstract}
A B S T R A C T
The effect of $\mathrm{UV} / \mathrm{Cl}_{2}$ disinfection on the biofilm and corrosion of cast iron pipes in drinking water distribution system were studied using annular reactors (ARs). Passivation occurred more rapidly in the $\mathrm{AR}$ with $\mathrm{UV} / \mathrm{Cl}_{2}$ than in the one with $\mathrm{Cl}_{2}$ alone, decreasing iron release for higher corrosivity of water. Based on functional gene, pyrosequencing assays and principal component analysis, UV disinfection not only reduced the required initial chlorine dose, but also enhanced denitrifying functional bacteria advantage in the biofilm of corrosion scales. The nitrate-reducing bacteria (NRB) Dechloromonas exhibited the greatest corrosion inhibition by inducing the redox cycling of iron to enhance the precipitation of iron oxides and formation of $\mathrm{Fe}_{3} \mathrm{O}_{4}$ in the $\mathrm{AR}$ with $\mathrm{UV} / \mathrm{Cl}_{2}$, while the rhizobia Bradyrhizobium and Rhizobium, and the NRB Sphingomonas, Brucella producing siderophores had weaker corrosion-inhibition effect by capturing iron in the $\mathrm{AR}$ with $\mathrm{Cl}_{2}$. These results indicated that the microbial redox cycling of iron was possibly responsible for higher corrosion inhibition and lower effect of water Larson-Skold Index (LI) changes on corrosion. This finding could be applied toward the control of water quality in drinking water distribution systems.
\end{abstract}

(c) 2014 Elsevier Ltd. All rights reserved.

\section{Introduction}

Iron and steel pipes have been used in water distribution systems for several centuries throughout the world, and are subjected to corrosion, causing deterioration of potable water quality due to unwanted chemical and biochemical reactions (McNeill and Edwards, 2001; Husband and Boxall, 2011). In the corrosion processes of iron pipes, iron ions were released into distributed water, and can re-precipitate forming corrosion scales, also referred to as tubercles (Gerke et al., 2008). The processes can greatly affect water quality in distribution system, not only by releasing iron oxyhydroxides (red water), but also by reactions with e.g. chlorinated disinfection byproducts (Chun et al., 2005), nitrates (Hansen et al., 1996) or natural organic matter (NOM) (Nawrocki et al., 2010). Typical iron corrosion products may be composed of the iron oxyhydroxides goethite $(\alpha-\mathrm{FeOOH})$ and lepidocrocite $(\Upsilon-\mathrm{FeOOH})$, magnetite $\left(\mathrm{Fe}_{3} \mathrm{O}_{4}\right)$, hematite $\left(\mathrm{Fe}_{2} \mathrm{O}_{3}\right)$, ferrous hydroxide $\left(\mathrm{Fe}(\mathrm{OH})_{2}\right)$, ferric hydroxide $\left(\mathrm{Fe}(\mathrm{OH})_{3}\right)$, and siderite $\left(\mathrm{FeCO}_{3}\right)$ (Wang et al., 2012). The exact composition and structure of iron corrosion scales, however, varies significantly with

\footnotetext{
* Corresponding author. Tel.: +8610 62849628; fax: +86 1062923541 .

E-mail address: huchun@rcees.ac.cn (C. Hu).
} 
water quality as well as the hydraulic conditions (Chun et al., 2005).

Recently, according to the report by Shi et al., in the drinking water distribution system of Beijing, dense corrosion scales were formed in pipes transporting surface water, while thin corrosion scales appeared in pipes transporting groundwater (Yang et al., 2012). Moreover, soon after $80 \%$ of the local source water was replaced by long-distance transported source water from a neighboring province in October, 2008, heavy red water occurred only in the pipes transporting groundwater, and the pipes transporting surface water did not encounter red water. The structure and character of corrosion scales on iron pipes could have great impact on the water quality in drinking water distribution systems (DWDS). Several environmental factors affect the corrosion rates and the composition of the corrosion products, such as metal type, chemical composition of the bulk water, electrochemistry, and microorganisms (Borenstein, 1994). Microbiologically influenced corrosion (MIC) has been of interest due to its complicated role in corrosion processes: it can either accelerate corrosion or inhibit corrosion. Recently more and more studies have begun to show protective effects by some bacterial biofilms on metal against corrosion (Zhang et al., 2010; Dubiel et al., 2002). For example, corrosion inhibition was caused by the reduction of ferric ions to ferrous ions and enhanced consumption of oxygen, both of which derive from iron-respiring bacteria respiration (Dubiel et al., 2002). The corrosion process and corrosion products can be affected by the bacterial characteristics of waters and biofilms in DWDS. However, the relationship between microorganisms and the character of corrosion scales in DWDS has still not been systemically investigated.

Disinfection is a key treatment step in biofilm control except pathogens, specifically premise plumbing pathogens control. Sequential UV chlor(am)ine disinfection is one potential way to control heterotrophic bacteria in distribution systems (Murphy et al., 2008). Rand et al. (2007) and Murphy et al. (2008) have also reported that sequential use of UV and chlorine could achieve greater log reductions in both effluent and biofilm than systems treated with chlorine-based disinfectants alone, maintaining water biological stability very well in drinking water distribution systems. However, to our knowledge, there were no studies to be conducted so far for characterization of bacterial community and corrosion with the combined disinfection process.

The objective of this study was to investigate the effects of the sequential use of UV light and chlorination on the corrosion of cast-iron coupons as well as biofilms and water quality in DWDS using annular reactors (ARs), with chlorination alone acting as a reference. In two ARs, the corrosion process and corrosion products were characterized by electrochemical and physicochemical measurements. Quantitative real-time PCR ( $q$ PCR) was used to monitor changes in the microbial community of biofilm inside corrosion scales according to specific groups: total bacteria by $16 \mathrm{~S}$ rRNA gene and denitrifiers by the functional genes nosZ, nirK and nirS. Pyrosequencing was used to monitor changes in diversity in the microbial community of biofilms, including corrosionrelated bacteria. The relationship of corrosion and biofilms was discussed.

\section{Materials and methods}

\subsection{Materials and preparation}

The cast iron coupons, with the composition of C $19.08 \%$, O $6.09 \%$, Si $2.06 \%$, Ca $0.58 \%$, P $0.65 \%$, S $1.60 \%$, Fe $65 \%$, Cu $1.98 \%$, Mn $0.92 \%$, Zn $2.04 \%$, were used in this study. Prior to experiment, the coupons were sequentially ground using a series of grit $(180,500,800$, and 1200) silicon carbide energy paper to a smooth surface. The polished coupons were rinsed with sterile deionized water thrice, degreased in acetone, followed by sterilizing in $70 \%$ ethanol for $8 \mathrm{~h}$, and then dried aseptically in a laminar flow cabinet. The coupons were exposed to UV light for $30 \mathrm{~min}$, then they were weighed prior to use.

\subsection{Model distribution system}

Two annular reactors (ARs) (Model 1320LJ, BioSurface Technologies Co., USA) were installed to simulate the drinking water distribution system. The ARs consisted of two concentric glass cylinders and a rotating inner drum that housed cast iron coupons (20 coupons in each reactor). Each coupon had an exposed surface area of $17.5 \mathrm{~cm}^{2}$ for biofilm growth. Two reactors were operated in parallel conditions, i.e., at a rotational speed of $50 \mathrm{rpm}$, which translated to a shear stress of $0.25 \mathrm{~N} / \mathrm{m}^{2}$, corresponding to a flow rate of approximately $0.3 \mathrm{~m} / \mathrm{sec}$ in a $100-\mathrm{mm}$-diameter smooth pipe (Wang et al., 2012). The hydraulic retention time for the reactors was $6 \mathrm{~h}$, as determined by the injection rate $(2.5 \mathrm{~mL} / \mathrm{min})$. All glass surfaces and any exposed surfaces were covered with aluminum foil to reduce the potential for phototrophic growth within the system.

In one AR system, water as influents was first treated with UV irradiation at a fluence of $40 \mathrm{~mJ} / \mathrm{cm}^{2}$. Prior to startup of the trial, the UV lamp was cleaned and soaked in $70 \%$ ethanol for $24 \mathrm{~h}$. The fluence was determined by ultraviolet irradiation meter. Then, the AR was conducted with free chlorine as the secondary disinfectant. Chlorine was dosed from a stock solution of sodium hypochlorite ( $\mathrm{NaClO})$. The other one AR was conducted with free chlorine as the secondary disinfectant only (Fig. S1). The two ARs were operated in two stages. At stage I, the initial chlorine concentration was about $0.85 \mathrm{mg} / \mathrm{L}$ in the influents with addition of $\mathrm{NaClO}$ in the two ARs. ARs were given 50 days to form a relatively stable corrosion scales. Then, at the stage II, in order to maintain the same effluent residual chlorine concentration of $0.08 \mathrm{mg} / \mathrm{L}$ in both ARs, different amount of $\mathrm{NaClO}$ was dosed into the influent. In addition, when the corrosion of iron coupons became steady on $300 \mathrm{~d}$ for the two ARs, the stability of the formed corrosion scales was examined by more corrosive water with the influent Larson-Skold index (LI) increasing. The influent LI 2, 4, 8 were obtained by adding $\mathrm{Na}_{2} \mathrm{SO}_{4}$ with the $\mathrm{SO}_{4}^{2-}$ concentration $182,412,872 \mathrm{mg} / \mathrm{L}$ in the $\mathrm{AR}$ with $\mathrm{Cl}_{2}$, and $187,417,878 \mathrm{mg} /$ $\mathrm{L}$ in the AR with $\mathrm{UV} / \mathrm{Cl}_{2}$, respectively. LI was calculated using the Eq. (1) (Ishii and Boyer, 2011):

$$
\mathrm{LI}=\frac{\left[\mathrm{Cl}^{-}\right]+2\left[\mathrm{SO}_{4}^{2-}\right]}{\left[\mathrm{HCO}_{3}^{-}\right]}
$$




\subsection{Water quality analysis}

The tested water (Table S1) was treated by chemical precipitation and flocculation, settling, sand filtration, and biologically-activated carbon filtration (prior to entering the chlorine contact tanks) in a drinking water treatment plant in north of China. All samples were stored at $4{ }^{\circ} \mathrm{C}$ before analysis and transporting into distribution systems.

Effluent samples were taken weekly from each AR. Water quality parameters, such as turbidity, anions, total iron and residual chlorine, were measured repeatedly for three times according to the standard methods (EPA of China 2002). Data for total iron and turbidity were the arithmetic mean of three measured values with error bars showing one standard deviation. Dissolved organic carbon was analyzed via a total organic carbon analyzer (Phoenix 8000; Tekmar-Dohrmann, USA). Differences in water quality parameters between the two ARs were analyzed using analysis of variance (ANOVA) with a significance threshold of $\alpha=0.05$. All information about sampling was shown in Supporting Information.

\subsection{Corrosion rate measurement}

Weight loss method was utilized to determine the corrosion rate. Briefly, the scraped coupons were rinsed with $70 \%$ ethanol, gently wiped with cotton swabs, freeze-dried for a day and weighted to determine the weight loss. The corrosion rate was calculated by using the formula below (ASTM G 31, 1994):

corrosion rate $(\mathrm{mm} /$ year $)=\frac{8.76 \times 10^{4} \times \mathrm{W}_{\text {loss }}}{\mathrm{A} \times \mathrm{D} \times \mathrm{T}}$

where $W_{\text {loss }}$ is weight loss in gram; $A$ is the surface area of the specimen in $\mathrm{cm}^{2}$; $D$ is the density of the test coupons in $\mathrm{g} / \mathrm{cm}^{3}$; and $\mathrm{T}$ is the corrosion time in $h$. In addition, all electrochemical measurements were described in supporting Information.

\subsection{Characterizing corrosion scales}

Crystalline phase was analyzed using an X-ray powder diffractometer (XRD, X'Pert PRO MPD; PANalytical, The Netherlands). The morphology of the corrosion products was examined by Filed Emission Scanning Electron Microscopy (FESEM, Hitachi, SU8020), operating at $1.0 \mathrm{kV}$.

\subsection{Pyrosequencing}

DNA was extracted in triplicate using the FastDNA spin kit for soil (Qbiogene, Solon, $\mathrm{OH}$ ) and mixed uniformly. All DNA samples were stored at $-80^{\circ} \mathrm{C}$ for future use. Primers $341 \mathrm{~F}\left(5^{\prime}\right.$ CCTACGGGAGGCAGCAG- $3^{\prime}$ ) and 1073R (5'-ACGAGCTGAC GACARCCATG-3') were used to amplify partial regions (V3-V6) of 16S rRNA genes (Lai et al., 2014). Each PCR product was tagged by inserting the 12-bp error- correcting Golay barcode to the forward primer and was gel-purified for pyrosequencing (Li et al., 2013). The pyrosequencing was performed on the GS FLX Titanium platform by Majorbio BioPharm Technology Co., Ltd. (Shanghai, China). All of the raw sequence data were processed using Mothur Software
(Zhao et al., 2011). Some Sequences were removed, including shorter than 200 bps, primer mismatches, and a quality score lower than 25. Mothur was used to cluster the operational taxonomic units (OTUs) based on $\geq 97 \%$ identity. Taxonomic positions of representative sequences were taxonomically assigned on the SILVA database (http://www.arb-silva.de/) (Zhao et al., 2013). Principal component analysis (PCA) has been used to correlate both physicochemical and clone library matrices (Bouskill et al., 2012). It was used to correlate the bacteria in genus level and corrosion current densities $\left(i_{\text {corr }}\right)$ in this paper by CANOCO program (CANOCO 4.5 for Windows).

\subsection{Quantitative PCR assay}

Primers targeting nirs, nirk, nosZ and 16S rRNA genes were utilized in quantitative PCR (qPCR) analysis via a 7300 qPCR system and the 7300 system SDS software (Applied Biosystems). The analysis procedures were described in Supporting Information.

\section{Results}

\subsection{Chlorine consumption and iron release}

In the two ARs before $50 \mathrm{~d}$ (stage I), the initial chlorine dose in the influents of ARs was around $0.85 \mathrm{mg} / \mathrm{L}$ while the residual chlorine in the effluent could hardly been detected to ensure that a relatively stable corrosion scale was established. No significant difference was observed in initial chlorine $(p=0.18)$ and residual chlorine $(p=0.53)$ between the two ARs at this period by ANOVA analysis (Fig. S2). In the AR with $\mathrm{UV} / \mathrm{Cl}_{2}$ at this stage, the total iron concentration of the effluents reached $0.52 \mathrm{mg} / \mathrm{L}$ within the first 20 days, then it gradually stabilized at approximately $0.11 \mathrm{mg} / \mathrm{L}$ around $50 \mathrm{~d}$ (Fig. 1A). For the AR with $\mathrm{Cl}_{2}$, total iron concentration was $0.25 \mathrm{mg} / \mathrm{L}$ over the first 20 days followed by stabilization at $0.1 \mathrm{mg} / \mathrm{L}$ (Fig. 1A). A similar result can be seen in the turbidity value with stabilization around $50 \mathrm{~d}$ (Fig. S3). The two ARs exhibited similar iron concentration $(p=0.37)$ and turbidity $(p=0.26)$ of effluents by ANOVA analysis. The changes of iron release and turbidity indicated that relatively stable corrosion scale was established at around $50 \mathrm{~d}$.

In stage II, for the same residual chlorine $(0.08 \mathrm{mg} / \mathrm{L})$ in the two ARs, a lower initial chlorine dose was required for the AR with $\mathrm{UV} / \mathrm{Cl}_{2}$ (average at $2.02 \mathrm{mg} / \mathrm{L}$ ) than that for the AR with $\mathrm{Cl}_{2}$ (average at $2.35 \mathrm{mg} / \mathrm{L}$ ). A significant difference was observed in initial chlorine dose $(p=0.0001)$ between the two ARs by ANOVA analysis. In addition, the required chlorine gradually decreased from $2.17 \mathrm{mg} / \mathrm{L}$ to $1.83 \mathrm{mg} / \mathrm{L}$ with increasing time in the $\mathrm{AR}$ with $\mathrm{UV} / \mathrm{Cl}_{2}$, indicating that the iron corrosion rate greatly decreased with time (Fig. S2). As to the iron release at stage II, the total iron concentration of the effluents in the AR with $\mathrm{UV} / \mathrm{Cl}_{2}$ was stable at a concentration around $0.11 \mathrm{mg} / \mathrm{L}$ (Fig. 1B), while in the AR with $\mathrm{Cl}_{2}$, there was an apparent increase (average at $0.20 \mathrm{mg} / \mathrm{L}$ ) in total iron release before $140 \mathrm{~d}$, followed by a stable total iron level at $0.14 \mathrm{mg} / \mathrm{L}$ (Fig. 1B). Overall, higher turbidity (average at $0.37 \mathrm{NTU}$ ) was measured in the effluents of the AR with $\mathrm{Cl}_{2}$ than that of the AR (average at $0.27 \mathrm{NTU}$ ) with $\mathrm{UV} / \mathrm{Cl}_{2}$ during stage II (Fig. S3). ANOVA 

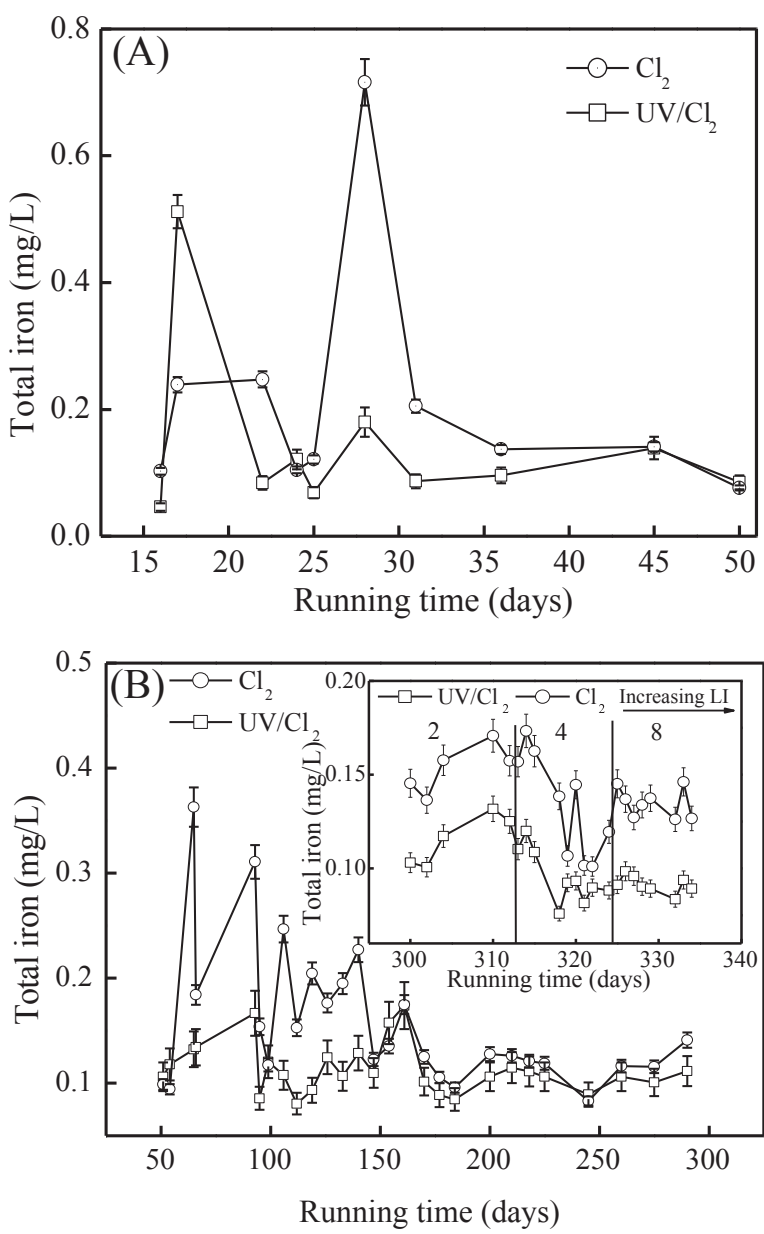

Fig. 1 - Diagram of total iron release before (A) and after (B) $50 \mathrm{~d}$ in effluents of two ARs. Error bars show one standard deviation.

analysis also showed that total iron $(p=0.0001)$ and turbidity $(p=0.003)$ were very different between the two ARs at stage II.

Some researches have indicated a significant linear relationship between iron release and the Larson-Skold index (LI), and high corrosion rates tended to result from waters with LI > 1.2 (Melidis et al., 2007; Ishii and Boyer, 2011). Therefore, the stability of the corrosion scales formed in the two ARs was examined by increasing water corrosivity with increasing LI after $300 \mathrm{~d}$. With the addition of $\mathrm{Na}_{2} \mathrm{SO}_{4}$, the $\mathrm{LI}$ of the influent increased from 1.2 to 2, 4 and 8. Correspondingly, the total iron (Fig. 1B) and turbidity (Fig. S3) in the effluent did not significantly change in the $\mathrm{AR}$ with $\mathrm{UV} / \mathrm{Cl}_{2}$, while higher total iron and turbidity appeared in the $\mathrm{AR}$ with $\mathrm{Cl}_{2}$ alone. A significant difference was observed in total iron $(p=0.001)$ and turbidity $(p=0.0001)$ between the two ARs by ANOVA analysis.

\subsection{Corrosion process with different disinfection}

Polarization curve and EIS measurements are electrochemical technique for the characterization of electrochemical reactions at the metal/biofilm interface and the formation of corrosion and biofilm (Mansfeld and Little, 1991; Yuan et al., 2007). In the experiment, polarization curves were measured for the corroded coupons in the two ARs (Fig. S4). The corrosion potentials, $E_{\text {corr }}$ and corrosion current densities were obtained by quantitative analysis (Table S2). In the AR with $\mathrm{UV} / \mathrm{Cl}_{2}$, corrosion current densities, $i_{\text {corr }}$, exhibited the highest value $54.85 \mu \mathrm{A} \mathrm{cm}^{-2}$ at $50 \mathrm{~d}$, then decreased to $27.5 \mu \mathrm{A} \mathrm{cm}^{-2}$ at $210 \mathrm{~d}$, and corrosion potentials, $E_{\text {corr }}$, underwent a slightly positive shift from $\sim-0.774$ to $\sim-0.664 \mathrm{~V}$ after $210 \mathrm{~d}$. The results indicated that the corrosion rate decreased after $50 \mathrm{~d}$, due to the inhibition effect of the corrosion layer on the electrode reactions. In contrast, in the $\mathrm{AR}$ with $\mathrm{Cl}_{2}$ alone, $i_{\text {corr }}$ increased and then decreased, indicating the corrosion rate increased with time before $140 \mathrm{~d}$, then decreased due to the formation of a corrosion oxide layer. Similarly, $E_{\text {corr }}$ exhibited a negative shift from $50 \mathrm{~d}$ to $140 \mathrm{~d}$, implying corrosion enhancement, then a slightly positive shift, indicating corrosion inhibition. The results indicated that after $140 \mathrm{~d}$, the corrosion reached a stable period, and a protective layer formed on the coupon in the DWDS with $\mathrm{Cl}_{2}$.

The impedance spectra of the corroded coupons exhibited different changes in the two ARs with exposure time (Fig. S5). Clearly, in the UV/Cl 2 DWDS, the diameter of the impedance loops markedly increased with time, indicating a decrease of the corrosion rate after $50 \mathrm{~d}$. However, in the $\mathrm{Cl}_{2}$ alone DWDS, the diameters of impedance loops decreased from $50 \mathrm{~d}$ to $140 \mathrm{~d}$, and later increased with time, indicating that the corrosion rate was accelerated before $140 \mathrm{~d}$, then the corrosion rate decreased. Furthermore, according to a described method (Gerengi et al., 2009), all impedance spectra were analyzed with an equivalent circuit, where $R_{s}$ refers to resistance of electrolytes in bulk, Rct refers to charge transfer resistance at metal surface, W refers to Warburg impedance, $Q$ refers to constant phase element of the electrical double layer (Fig. S6). The analyzed values showed that Q parameter meaning double layer capacitance gradually decreased, while the charge transfer resistance, Rct increased with time, confirming improvement of corrosion inhibition with time in the AR with $\mathrm{UV} / \mathrm{Cl}_{2}$ (Table S2). Differently, in the $\mathrm{AR}$ with $\mathrm{Cl}_{2}$ alone, before $140 \mathrm{~d}$, the $\mathrm{Q}$ increased, while Rct decreased with time, indicating an increase in the corrosion rate of the iron coupons. After $140 \mathrm{~d}$, the $\mathrm{Q}$ decreased, and Rct increased with time, indicating enhancement of corrosion inhibition with time (Table S2). Similarly, for stage I and stage II, the average weight loss values of the corrosion coupons were about 0.287 and $0.153 \mathrm{~mm}$ /year in the $\mathrm{AR}$ with $\mathrm{UV} / \mathrm{Cl}_{2}$, while that ones were about 0.195 and $0.168 \mathrm{~mm}$ /year, which confirmed the results of electrochemical measurements (Table 1).

\subsection{Characterization of corrosion scales}

Fig. 2 shows the XRD patterns of different corrosion scales on iron coupons in the two ARs. Green rusts were observed in

Table 1 - Corrosion rate (mm/year) in two ARs at different running stages ${ }^{a}$

\begin{tabular}{lcl} 
& AR with $\mathrm{UV} / \mathrm{Cl}_{2}$ & AR with $\mathrm{Cl}_{2}$ \\
\hline Stage I & $0.287 \pm 0.015$ & $0.195 \pm 0.03$ \\
Stage II & $0.153 \pm 0.011$ & $0.168 \pm 0.006$ \\
\hline
\end{tabular}

a Values are mean \pm standard deviation of two replicates. 
corrosion scales of both ARs at stage I, which were layered double hydroxides containing $\mathrm{Fe}(\mathrm{II})$ and $\mathrm{Fe}(\mathrm{III})$, then disappeared in scales at stage II. Goethite $(\alpha-\mathrm{FeOOH})$, Calcite $\left(\mathrm{CaCO}_{3}\right)$, and Magnetite $\left(\mathrm{Fe}_{3} \mathrm{O}_{4}\right)$ also were detected in all samples, however, their intensities were higher in the AR with UV/ $\mathrm{Cl}_{2}$ than those in the AR with $\mathrm{Cl}_{2}$. In addition, the SEM micrographs of corrosion scales on the cast iron coupons under different conditions were obtained (Fig. S7). The corrosion products gradually formed round particles with increasing time in the AR with $\mathrm{UV} / \mathrm{Cl}_{2}$, while the products formed in the AR with $\mathrm{Cl}_{2}$ alone exhibited a laminar structure at stage I, and partly converted into round particles with increasing time, implying the round particles were more stable. The results also indicated that the stable protective layer formed faster in the $\mathrm{AR}$ with $\mathrm{UV} / \mathrm{Cl}_{2}$ than in the $\mathrm{AR}$ with $\mathrm{Cl}_{2}$ alone.

\subsection{Denitrifying functional gene abundance of biofilm}

It has been reported that the oxidation and reduction of iron were induced by respiration of some denitrifying bacteria (Weber et al., 2006a). Therefore, denitrifying functional genes were analyzed quantitatively by qPCR. Fig. 3 shows the nosZ,
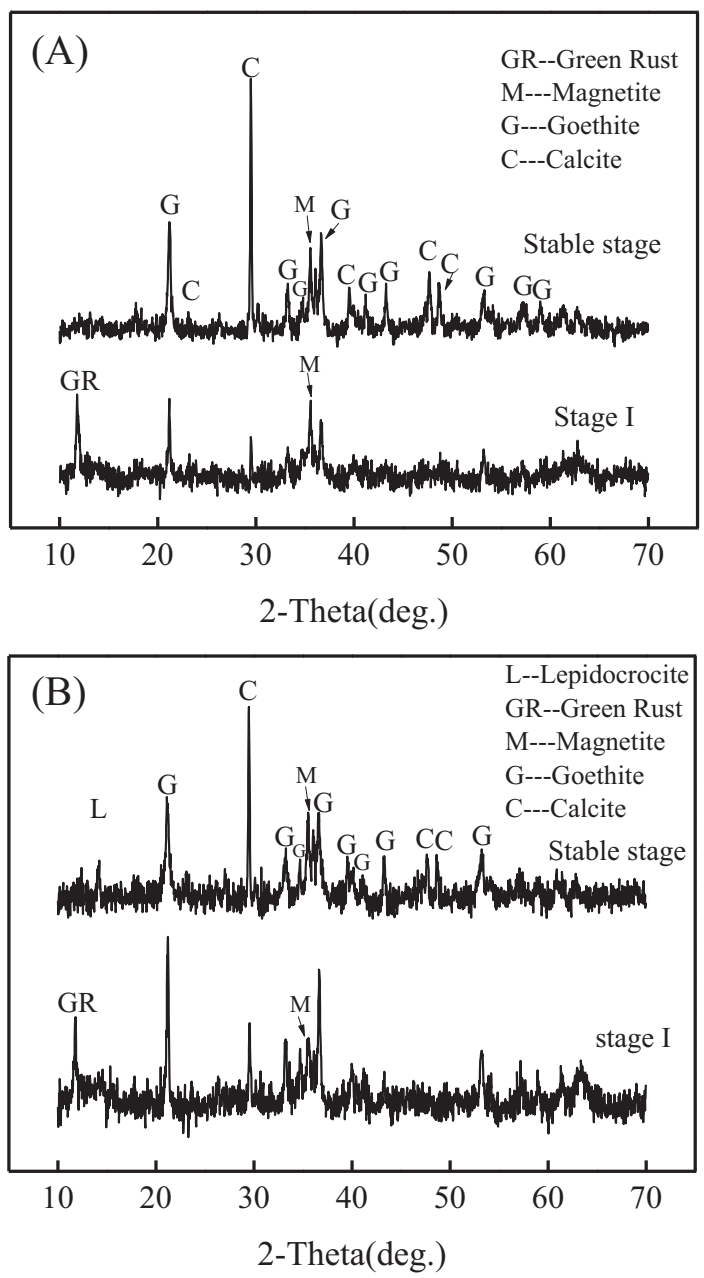

Fig. 2 - X-ray diffraction (XRD) patterns of corrosion scales on iron coupons at different stages in the $\mathrm{AR}$ with $\mathrm{UV} / \mathrm{Cl}_{2}$ (A) and $\mathrm{Cl}_{2}$ alone (B).
nirS, nirK, and 16S rRNA gene copy numbers of biofilm at different stages for the two ARs. The 16S rRNA gene increased through all stages, indicating an increase of microbial biomass. At stage II, the two ARs had nearly same 16S rRNA gene copy numbers, indicating same microbial biomass. However, the denitrifying functional gene copy numbers exhibited different changes with time in the two ARs. The three functional gene numbers greatly increased with increasing $16 \mathrm{~S}$ rRNA gene numbers in the $\mathrm{AR}$ with $\mathrm{UV} / \mathrm{Cl}_{2}$, the nirs increased from $5.73 \times 10^{7}$ to $1.64 \times 10^{10}$ copies/g (Fig. 3), and the total denitrifying gene numbers were $33.1 \%$ of $16 \mathrm{~S}$ rRNA at stage II (Fig. S8). In the AR with $\mathrm{Cl}_{2}$, the three functional gene numbers slightly increased, and the total denitrifying gene numbers were $15.1 \%$ of $16 \mathrm{~S}$ rRNA at stage II (Fig. S8).

Correspondingly, in bulk water, total of denitrifying functional genes exhibited a great increase at stage II through the AR with $\mathrm{UV} / \mathrm{Cl}_{2}$, while that one did not greatly change at stage I and stage II in the AR with $\mathrm{Cl}_{2}$ alone. The 16S rRNA gene copy numbers decreased through all stages for the two ARs (Fig. S9). Significantly, the 16S rRNA gene copy numbers in bulk water with $\mathrm{UV} / \mathrm{Cl}_{2}$ were smaller than that ones with $\mathrm{Cl}_{2}$ alone, indicating the more inactivation of bacteria by UV (Fig. S9).

\subsection{Bacterial community structure of biofilms}

Pyrosequencing yielded a total of 27,032 high-quality sequences of the 16S rRNA gene for all samples. Table S3 shows the observed OTUs and diversity indexes of the bacteria phylotypes. Meanwhile, the estimated Shannon index for all samples expressed lower diversity of microbial community at stage II for both reactors. The OTU richness expressed by Chao 1 index indicates the highest OTU richness in $\mathrm{UV} / \mathrm{Cl}_{2}$ reactor at stage I. The taxonomic breakdown at the class level was provided for all samples (Fig. S10). The bacterial community composition exhibited notable differences in the two ARs at different stages. In the $\mathrm{AR}$ with $\mathrm{UV} / \mathrm{Cl}_{2}$, at stage I, Alphaproteobacteria (48\%) was the dominant class, other minor classes were Actinobacteria (15\%), Acidobacteria (10\%), Acidimicrobidae

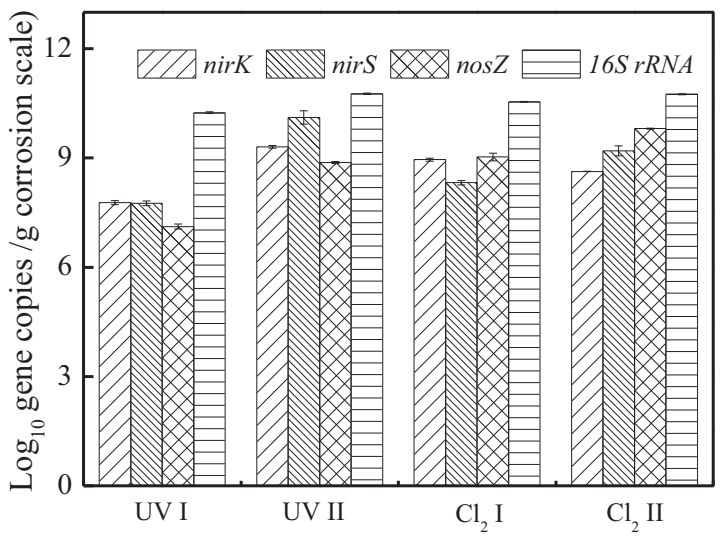

Fig. 3 - Quantitative PCR results on nirK, nirS, nosZ and 16S rRNA gene copy numbers in biofilm of different corrosion scales (expressed as $\log _{10}$ gene copies per gram of corrosion scales). Error bars represented the standard deviation from the average. 
(6\%), Gammaproteobacteria (4\%) and Betaproteobacteria (3\%), while at stage II, Betaproteobacteria became the most abundant class (55\%), Alphaproteobacteria, Acidobacteria and Actinobacteria decreased to $28 \%, 2 \%$ and $2 \%$ respectively. In the $\mathrm{AR}$ with $\mathrm{Cl}_{2}$ alone, at stage I, the major classes were Alphaproteobacteria (39\%) and Actinobacteria (32\%), the minor groups were Betaproteobacteria (7\%) and Gammaproteobacteria (5\%) and Thermoleophilia (6\%), while at stage II, Alphaproteobacteria and Betaproteobacteria dramatically increased to $62 \%$ and $27 \%$ respectively. Other classes greatly decreased to less than $3 \%$.

Furthermore, the community structures of these dominant bacteria are compared at the genus level for different biofilms (Fig. 4). The compositions of bacteria related with iron cycling underwent great changes in different ARs and different stages. In the AR with $\mathrm{UV} / \mathrm{Cl}_{2}$, at stage I, the relative abundance of nitrate-reducing bacteria (NRB) was 9.9\%, and among them, 3.9\% NRB were related to redox cycling of iron, such as Hyphomicrobium (3.7\%) (Stein et al., 2001), and 6\% NRB produced siderophores, including Sphingomonas (Duckworth et al., 2009), Brucella (Roop, 2012), Acinetobacter (Proschak et al., 2013) and Azospirillum (Loaces et al., 2011). The ironrespiring bacteria were $11.7 \%$, predominantly including ironreducing bacteria (IRB) Acidobacterium (10.2\%) (Nancucheo and Johnson, 2010) and iron-oxidizing bacteria (IOB) Pedomicrobium (1.3\%) (Braun et al., 2009). The rhizobia including Bradyrhizobium, Rhizobium and Mesorhizobium were 2.3\%, which produced siderophores (Arif et al., 2012). At stage II, the dominant genera NRB were $64.1 \%$, and among them, Dechloromonas (Weber et al., 2006a) and Hyphomicrobium were $45.23 \%$ and $1.3 \%$ inducing redox of iron, and $17.5 \%$ NRB produced siderophores. While IRB, including Rhodobacter (Dobbin et al., 1996), Ferribacterium (Cummings et al., 1999), Acidobacterium and Albidiferax (Lu et al., 2013), decreased to 3.6\%, and IOB such as Sediminibacterium (Wang et al., 2012) and Pedomicrobium were $0.5 \%$, the rhizobia were $2.6 \%$. In the $\mathrm{AR}$ with $\mathrm{Cl}_{2}$ alone, at stage I, the relative abundance of the same rhizobia was $7.7 \%$, including Bradyrhizobium, Rhizobium and Mesorhizobium, while the relative abundance of NRB was $12.8 \%$, including $6.5 \%$ NRB inducing redox of iron, such as Hyphomicrobium (3.5\%) and Herbaspirillum (3\%) (Geissler et al., 2011), and 6.3\% NRB producing siderophores, such as Sphingomonas, Acinetobacter and

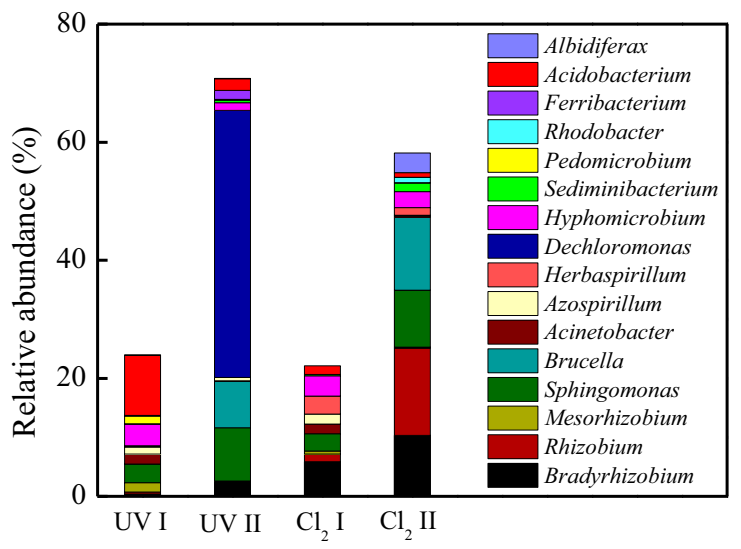

Fig. 4 - Corrosion-related bacterial genera by relative abundance in biofilms from different corrosion scales.
Azospirillum. The IRB Acidobacterium was at $1.5 \%$. At stage II, the relative abundance of the rhizobia increased to $25.3 \%$, and the NRB increased to $26.3 \%$; however, among them, the NRB associated with iron redox cycling decreased to $4 \%$, while the NRB producing siderophores were at $22.3 \%$, including Sphingomonas, Brucella, Acinetobacter and Azospirillum. The IRB Albidiferax became $3.3 \%$ of the total bacteria. Therefore, the changes of NRB relative abundance were agreed with those ones of denitrifying functional gene numbers in the two ARs. The results indicated that UV disinfection enhanced denitrifying functional bacteria advantage in the biofilm of corrosion scales.

\section{Discussion}

The combination of UV irradiation as a primary disinfectant and free chlorine as a secondary disinfectant has been shown not only to prevent subsequent microbial regrowth but also to produce a synergetic disinfection (Shang et al., 2007). Therefore, the UV inactivation of bacteria in the influent possibly leaded to the advantage of denitrifying functional bacteria in biofilm and bulk water through the AR with $\mathrm{UV} / \mathrm{Cl}_{2}$. On the other hand, the above corrosion data suggested that different bacterial community composition of biofilm may affect the corrosion process of iron. Although at stage I, there were same water chemical parameters due to same initial chlorine dose, different corrosion rate occurred in the two ARs, indicating microorganism played a great role in the corrosion of iron. Moreover, at stage II, in order to maintain same residual chlorine $(0.08 \mathrm{mg} / \mathrm{L})$, a less initial chlorine dose was required in the $\mathrm{AR}$ with $\mathrm{UV} / \mathrm{Cl}_{2}$ than that one with $\mathrm{Cl}_{2}$ alone. The results suggested that less chlorine was consumed by the corrosion in the AR with $\mathrm{UV} / \mathrm{Cl}_{2}$, indicating the tested chlorine dose had less influence than microorganism on the corrosion under the experimental conditions.

Principal component analysis (PCA) was used to correlate the corrosion-related bacteria in genus level and the corrosion current density ( $\left.i_{\text {corr }}\right)$ in this research (Fig. 5). The biofilm in the two ARs at stage I, including the genera Pedomicrobium (IOB), Acidobacterium (IRB), Hyphomicrobium (NRB) and Herbaspirillum (NRB), was positively correlated with $i_{\text {corr }}$, enhancing corrosion of iron coupon. Glycolic acid was produced by the growth of Acidobacterium, leading extremely acidic environments to enhancing corrosion of iron coupon, while Hyphomicrobium and Herbaspirillum were related to nitrate-dependent Fe(II) oxidation, they and IOB Pedomicrobium played corrosive role for the iron coupons at stage I. In the AR with $\mathrm{UV} / \mathrm{Cl}_{2}$, Acidobacterium, Hyphomicrobium and Pedomicrobium were dominant for $10.2 \%, 3.7 \%$ and $1.29 \%$ respectively. Moreover, their total relative abundances were higher than those of Hyphomicrobium (3.45\%), Acidobacterium (1.48\%) and Herbaspirillum (3.02\%) in $\mathrm{AR}$ with $\mathrm{Cl}_{2}$, leading to higher corrosion rate and faster precipitation of iron oxides in the $\mathrm{AR}$ with $\mathrm{UV} / \mathrm{Cl}_{2}$ at stage I.

At the stage II, with the formation of corrosion layer, the biofilms in the two ARs exhibited negative correlation with $i_{\text {corr, }}$ indicating microbial corrosion inhibition. The main bacteria were Dechloromonas, Ferribacterium, Sphingomonas, Brucella, Sediminibacterium, Bradyrhizobium, Rhodobacter, Albidiferax 


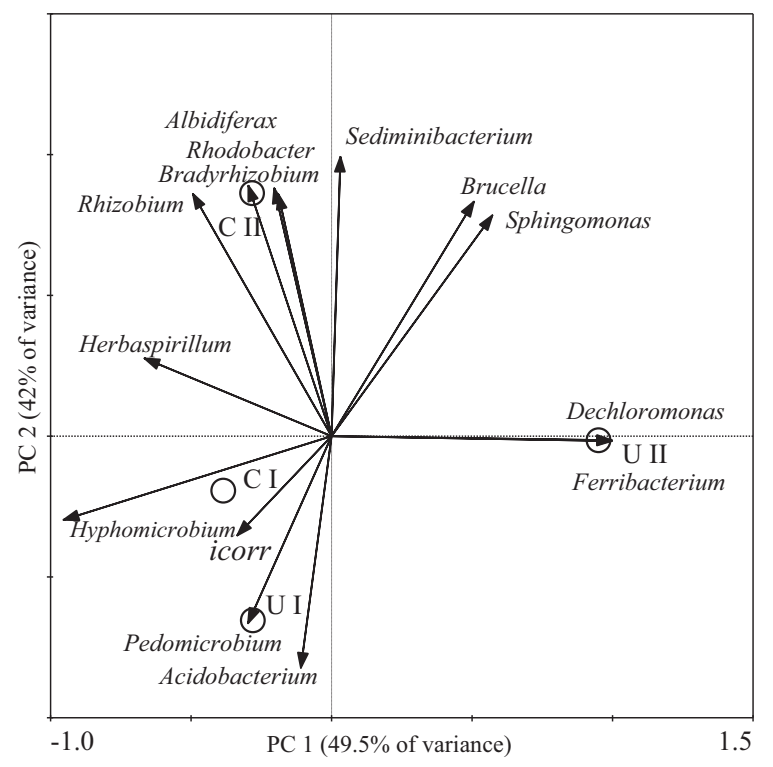

Fig. 5 - Principal component analysis (PCA) based on a correlation matrix combining corrosion current density ( $\left.i_{\text {corr }}\right)$ and the abundance of corrosion-related genera in the biofilm of cast iron coupons. (UI, UII, CI, CII represented the sample from $\mathrm{AR}$ with $\mathrm{UV} / \mathrm{Cl}_{2}$ and $\mathrm{AR}$ with $\mathrm{Cl}_{2}$ alone at stage I and stage II, respectively.

and Rhizobium in the following order of decreasing effect of the genera on $i_{\text {corr. }}$. It indicated that Dechloromonas (NRB) and Ferribacterium (IRB) played a great role in the corrosion inhibition of cast iron coupons. The two genera only presented in the AR with $\mathrm{UV} / \mathrm{Cl}_{2}$, at stage II, and the relative abundance of Dechloromonas (NRB) was $45.23 \%$, correspondingly, the denitrifying functional gene copy numbers were $33.1 \%$. The results indicated most of Dechloromonas had denitrifying function. It has been reported that in $\mathrm{NO}_{3}^{-}$concentration less than $31 \mathrm{mg} / \mathrm{L}$, the oxidation and reduction of iron occurred simultaneously by the respiration of Dechloromonas, resulting in $\mathrm{Fe}_{3} \mathrm{O}_{4}$ formation (Weber et al., 2006a, 2006b). Under the above conditions, the cycling of $\mathrm{Fe}(\mathrm{II}) / \mathrm{Fe}(\mathrm{III})$ were driven by Dechloromonas because the concentration of $\mathrm{NO}_{3}^{-}$was less than $10 \mathrm{mg} / \mathrm{L}$ in the influent, and the interaction of iron and NRB could enhance the precipitation of iron oxide, the formation of $\mathrm{Fe}_{3} \mathrm{O}_{4}$ and consumption of oxygen, causing higher corrosion inhibition. The next corrosion-inhibition bacteria Sphingomonas (9.03\%), Brucella (7.84\%) produced and imported siderophores to be biochelators capturing iron to inhibit the dissolution of iron and iron corrosion (Grateron et al., 2007; Little et al., 2007; Raymond and Dertz, 2004). These microbial roles could avoid the iron release when the corrosivity of influent water increased in the $\mathrm{AR}$ with $\mathrm{UV} / \mathrm{Cl}_{2}$. In contrast, the main corrosion-inhibition bacteria were these bacteria produced siderophores, including Sphingomonas (9.64\%), Bradyrhizobium (10.4\%), Brucella (12.31\%) and Rhizobium (14.7\%) in the AR with $\mathrm{Cl}_{2}$, while the NRB related with iron cycling was very low. The main corrosion inhibition was carried out by siderophores capturing iron from these bacteria growth. The lower corrosion-inhibition effect leaded to the higher iron release for higher corrosivity of influent water in the AR with $\mathrm{Cl}_{2}$.

\section{Conclusions}

The results verified that the corrosion occurred faster and was more rapidly inhibited to form more stable protective layer in the $\mathrm{AR}$ with $\mathrm{UV} / \mathrm{Cl}_{2}$ than in that one with $\mathrm{Cl}_{2}$ alone. UV disinfection not only reduced the required initial chlorine dose, but also enhanced denitrifying functional bacteria advantage in the biofilm of corrosion scales. PCA analysis showed that the NRB Dechloromonas and IRB Ferribacterium exhibited greatest inhibition effect on the iron corrosion, while the rhizobia Bradyrhizobium and Rhizobium, and the NRB Sphingomonas and Brucella presented weaker effect on the corrosion inhibition. The NRB Dechloromonas was main corrosion-inhibition bacteria in the $\mathrm{AR}$ with $\mathrm{UV} / \mathrm{Cl}_{2}$. Its metabolism induced the cycling of $\mathrm{Fe}(\mathrm{II}) / \mathrm{Fe}(\mathrm{III})$ to increase the precipitation of iron oxides and $\mathrm{Fe}_{3} \mathrm{O}_{4}$ formation, enhancing the stability of corrosion scales, inhibiting the iron release for influent water with higher corrosivity. In the AR with $\mathrm{Cl}_{2}$, the dominant rhizobia and NRB Sphingomonas Brucella inhibited the corrosion by producing siderophores to capture iron, leading slower corrosion inhibition, which was contributed to the iron release for the higher influent water corrosivity.

\section{Acknowledgments}

This work was supported by the National Natural Science Foundation of China (Grant Nos. 21125731, 51290281, 51221892) and the project of Chinese Academy of Sciences (Grant No. YSW2013A02).

\section{Appendix A. Supplementary data}

Supplementary data related to this article can be found at http://dx.doi.org/10.1016/j.watres.2014.04.035.

\section{R E F E R E N C E S}

Arif, K., Archana, G., Anjana, D.J., 2012. Engineering heterologous iron siderophore complex utilization in rhizobia: effect on growth of peanut and pigeon pea plants. Appl. Soil. Ecol. 53, 65-73.

ASTM Standard G 31, 1994. Standard practice for laboratory immersion corrosion testing of metals. In: Annual Book of ASTM Standards, vol. 03. ASTM International, West Conshohocken, PA, 02.

Borenstein, S.W., 1994. Microbiologically in Corrosion Handbook. Woodhead Publishing.

Bouskill, N.J., Eveillard, D., Chien, D., Jayakumar, A., Ward, B.B., 2012. Environmental factors determining ammonia-oxidizing organism distribution and diversity in marine environments. Environ. Microbiol. 14 (3), 714-729.

Braun, B., Richert, I., Szewzyk, U., 2009. Detection of irondepositing Pedomicrobium species in native biofilms from the Odertal National Park by a new, specific FISH probe. J. Microbiol. Methods 79 (1), 37-43. 
Chun, C.L., Hozalski, R.M., Arnold, W.A., 2005. Degradation of drinking water disinfection byproducts by synthetic goethite and magnetite. Environ. Sci. Technol. 39 (21), 8525-8532.

Cummings, D.E., Caccavo, F., Spring, S., Rosenzweig, R.F., 1999. Ferribacterium limneticum, gen. nov., sp. nov., an Fe(III)reducing microorganism isolated from mining-impacted freshwater lake sediments. Archives Microbiol. 171 (3), 183-188.

Dobbin, P.S., Warren, L.H., Cook, N.J., McEwan, A.G., Powell, A.K., Richardson, D.J., 1996. Dissimilatory iron(III) reduction by Rhodobacter capsulatus. Microbiology 142 (4), 765-774.

Dubiel, M., Hsu, C.H., Chien, C.C., Mansfeld, F., Newman, D.K., 2002. Microbial iron respiration can protect steel from corrosion. Appl. Environ. Microbiol. 68 (3), 1440-1445.

Duckworth, O.W., Holmstroem, S.J.M., Pena, J., Sposito, G., 2009. Biogeochemistry of iron oxidation in a circumneutral freshwater habitat. Chem. Geol. 260 (3-4), 149-158.

EPA of China, 2002. Analysis Method for Water and Waster Water, fourth ed. Press of Chinese Environmental Science.

Geissler, A., Law, G.T.W., Boothman, C., Morris, K., Burke, I.T., Livens, F.R., Lloyd, J.R., 2011. Microbial communities associated with the oxidation of iron and technetium in bioreduced sediments. Geomicrobiol. J. 28 (5-6), 507-518.

Gerengi, H., Darowicki, K., Bereket, G., Slepski, P., 2009. Evaluation of corrosion inhibition of brass-118 in artificial seawater by benzotriazole using dynamic EIS. Corros. Sci. 51 (11), 2573-2579.

Gerke, T.L., Maynard, J.B., Schock, M.R., Lytle, D.L., 2008. Physiochemical characterization of five iron tubercles from a single drinking water distribution system: possible new insights on their formation and growth. Corros. Sci. 50 (7), 2030-2039.

Grateron, C., Barbosa, O., Rueda, N., Ortiz-Lopez, C., Torres, R., 2007. AS7, a bacterial siderophore valuable as a high performance corrosion inhibitor. J. Biotechnol. 131 (2), S87-S88.

Hansen, H.C.B., Koch, C.B., NanckeKrogh, H., Borggaard, O.K., Sorensen, J., 1996. Abiotic nitrate reduction to ammonium: key role of green rust. Environ. Sci. Technol. 30 (6), 2053-2056.

Husband, P.S., Boxall, J.B., 2011. Asset deterioration and discolouration in water distribution systems. Water Res. 45 (1), 113-124.

Ishii, S.K.L., Boyer, T.H., 2011. Evaluating the secondary effects of magnetic ion exchange: focus on corrosion potential in the distribution system. Desalination 274 (1-3), 31-38.

Lai, C.Y., Yang, X., Tang, Y., Rittmann, B.E., Zhao, H.P., 2014. Nitrate shaped the selenate-reducing microbial community in a hydrogen-based biofilm reactor. Environ. Sci. Technol. 48 (6), 3395-3402.

Li, D., Alidina, M., Ouf, M., Sharp, J.O., Saikaly, P., Drewes, J.E., 2013. Microbial community evolution during simulated managed aquifer recharge in response to different biodegradable dissolved organic carbon (BDOC) concentrations. Water Res. 47 (7), 2421-2430.

Little, B., Lee, J., Ray, R., 2007. A review of 'green' strategies to prevent or mitigate microbiologically influenced corrosion. Biofouling 23 (2), 87-97.

Loaces, I., Ferrando, L., Scavino, A.F., 2011. Dynamics, diversity and function of endophytic siderophore-producing bacteria in rice. Microb. Ecol. 61 (3), 606-618.

Lu, S., Chourey, K., Reiche, M., Nietzsche, S., Shah, M.B., Neu, T.R., Hettich, R.L., Kusel, K., 2013. Insights into the structure and metabolic function of microbes that shape pelagic iron-rich aggregates ("iron snow"). Appl. Environ. Microbiol. 79 (14), $4272-4281$.

Mansfeld, F., Little, B., 1991. A technical review of electrochemical techniques applied to microbiologically influenced corrosion. Corros. Sci. 32 (3), 247-272.
McNeill, L.S., Edwards, M., 2001. Iron pipe corrosion in distribution systems. J. Am. Water Works Assoc. 93 (7), 88-100.

Melidis, P., Sanozidou, M., Mandusa, A., Ouzounis, K., 2007. Corrosion control by using indirect methods. Desalination 213 (1-3), 152-158.

Murphy, H.M., Payne, S.J., Gagnon, G.A., 2008. Sequential UV- and chlorine-based disinfection to mitigate Escherichia coli in drinking water biofilms. Water Res. 42 (8-9), 2083-2092.

Nancucheo, I., Johnson, D.B., 2010. Production of glycolic acid by chemolithotrophic iron- and sulfur-oxidizing bacteria and its role in delineating and sustaining acidophilic sulfide mineraloxidizing consortia. Appl. Environ. Microbiol. 76 (2), 461-467.

Nawrocki, J., Raczyk-Stanislawiak, U., Swietlik, J., Olejnik, A., Sroka, M.J., 2010. Corrosion in a distribution system: steady water and its composition. Water Res. 44 (6), 1863-1872.

Proschak, A., Lubuta, P., Gruen, P., Loehr, F., Wilharm, G., De Berardinis, V., Bode, H.B., 2013. Structure and biosynthesis of fimsbactins A-F, siderophores from Acinetobacter baumannii and Acinetobacter baylyi. ChemBioChem 14 (5), 633-638.

Rand, J.L., Hofmann, R., Alam, M.Z.B., Chauret, C., Cantwell, R., Andrews, R.C., Gagnon, G.A., 2007. A field study evaluation for mitigating biofouling with chlorine dioxide or chlorine integrated with UV disinfection. Water Res. 41 (9), 1939-1948.

Raymond, K.N., Dertz, E.A., 2004. Biochemical and Physical Properties of Siderophores. ASM Press.

Roop II, R.M., 2012. Metal acquisition and virulence in Brucella. Animal Health Res. Rev. 13 (1), 10-20.

Shang, C., Cheung, L.M., Liu, W., 2007. MS2 coliphage inactivation with UV irradiation and free chlorine/monochloramine. Environ. Eng. Sci. 24 (9), 1321-1332.

Stein, L.Y., La Duc, M.T., Grundl, T.J., Nealson, K.H., 2001. Bacterial and archaeal populations associated with freshwater ferromanganous micronodules and sediments. Environ. Microbiol. 3 (1), 10-18.

Wang, H.B., Hu, C., Hu, X.X., Yang, M., Qu, J.H., 2012. Effects of disinfectant and biofilm on the corrosion of cast iron pipes in a reclaimed water distribution system. Water Res. 46 (4), 1070-1078.

Weber, K.A., Urrutia, M.M., Churchill, P.F., Kukkadapu, R.K., Roden, E.E., 2006a. Anaerobic redox cycling of iron by freshwater sediment microorganisms. Environ. Microbiol. 8 (1), 100-113.

Weber, K.A., Achenbach, L.A., Coates, J.D., 2006b. Microorganisms pumping iron: anaerobic microbial iron oxidation and reduction. Nat. Rev. Microbiol. 4 (10), 752-764.

Yang, F., Shi, B.Y., Gu, J.N., Wang, D.S., Yang, M., 2012. Morphological and physicochemical characteristics of iron corrosion scales formed under different water source histories in a drinking water distribution system. Water Res. 46 (16), 5423-5433.

Yuan, S.J., Choong, A.M.F., Pehkonen, S.O., 2007. The influence of the marine aerobic Pseudomonas strain on the corrosion of 70/30 Cu-Ni alloy. Corros. Sci. 49 (12), 4352-4385.

Zhang, Y., Griffin, A., Edwards, M., 2010. Effect of nitrification on corrosion of galvanized iron, copper, and concrete. J. Am. Water Works Assoc. 102 (4), 83-93.

Zhao, H.P., Van Ginkel, S., Tang, Y.N., Kang, D.W., Rittmann, B., Krajmalnik-Brown, R., 2011. Interactions between perchlorate and nitrate reductions in the biofilm of a hydrogen-based membrane biofilm reactor. Environ. Sci. Technol. 45 (23), 10155-10162.

Zhao, H.P., Ontiveros-Valencia, A., Tang, Y.N., Kim, B.O., Ilhan, Z.E., Krajmalnik-Brown, R., Rittrnann, B., 2013. Using a two-stage hydrogen-based membrane biofilm reactor (MBfR) to achieve complete perchlorate reduction in the presence of nitrate and sulfate. Environ. Sci. Technol. 47 (3), 1565-1572. 